\title{
Desain Pembelajaran Pecahan melalui Pendekatan Realistik di Kelas V
}

\author{
Warsito $^{1 *}$, Yeni Nuraini' ${ }^{2}$ dan Sukirwan ${ }^{3}$ \\ Universitas Muhammadiyah Tangerang \\ Jalan Perintis Kemerdekaan I/33 Tangerang \\ 1*2warsito@umt.ac.id \\ Unversitas Sultan Ageng Tirtayasa \\ Jalan Raya Jakarta Km.4 Kota Serang Banten \\ ${ }^{3}$ sukirwan@untirta.ac.id
}

Artikel diterima: 02-10-2018, direvisi: 31-01-2019, diterbitkan: 31-01-2019

\begin{abstract}
Abstrak
Pecahan merupakan salah satu topik matematika yang hampir selalu menjadi masalah bagi siswa sekolah dasar (SD). Masalah tersebut muncul karena umumnya siswa tidak memahami konsep pecahan. Penelitian ini merupakan penelitian desain (design research) yang dirancang untuk memberikan suatu pertimbangan yang baik terhadap proses pembelajaran operasi pecahan melalui dugaan-dugaan yang dibangun dalam kerangka analisis hypotetical learning trajectory (HLT) yang kemudian diujicobakan dalam pembelajaran matematika realistik (PMR). PMR mendasari dari seluruh kegiatan penelitian desain riset. Hasil penelitian ini tergambar dari teori instruksional lokal (local instructional theory). Design research dilakukan dalam tiga tahap, yaitu desain pendahuluan, percobaan mengajar yang terdiri siklus 1 dan siklus 2 , dan tahap ketiga analisis retrospektif. Penelitian melibatkan menggunakan sampel sebanyak 29 siswa kelas V di SDI Nurul Hasanah yang terdiri 4 orang siswa pada siklus satu dan 25 siswa pada siklus kedua. Hasil penelitian dapat menunjukan bahwa serangkaian kegiatan pembelajaran dengan PMR dapat membawa siswa dari situasi konkret menuju situasi yang lebih formal. Siswa mampu mengerjakan bilangan pecahan dari bentuk kontektual dengan disertai alasan.

Kata Kunci: Design research, pembelajaran matematika realistik, hypotetical learning trajectory, dan local instructional theory.
\end{abstract}

\section{Learning Design Fractions through Realistic Approach in Class V}

\section{Abstract}

Fractions is one of the mathematics topic that are almost to be problem for elementary school (SD). This problem arises because generally studenst do no understand about concept of fraction. This research is design research designed to provide a good consideration of learning process of fractional operations through allegations built in framework analysis hypotetical learning trajectory (HLT), which later tested in learning mathematics realistic (PMR). PMR underlies all research design research activities. The results of this study are drawn from local instructional theory. Design research is carried out in three stages, namely preliminary design, teaching experiment consisting of cycle 1 and cycle 2, and the third stage of retrospective analysis. The study involved using a sample of 29 grade $V$ students at SDI Nurul Hasanah consisting of 4 students in cycle one and 25 students in the second cycle. The results of the study can show that a series of learning activities with PMR can bring students from concrete situations to a more formal situation. Students are able to work fractions of a contextual form with reason.

Keyword: Design research, realistic mathematics education, hypothetical learning trajectory, and local instructional theory. 


\section{Pendahuluan}

Pada level sekolah dasar, pelajaran matematika merupakan salah satu mata pelajaran yang perlu mendapat perhatian khusus. Selain karena dianggap sulit oleh siswa, pelajaran matematika adalah tonggak awal pengetahuan matematika untuk jenjang berikutnya. Dengan demikian, keberhasilan pada jenjang sekolah dasar akan berpengaruh pada keberhasilan pembelajaran matematika pada jenjang berikutnya. Mengacu pada tujuan operasional pendidikan dasar (Anwar, 2012), matematika adalah bagian dari keterampilan berhitung yang harus dikuasai siswa sekolah dasar. Keterampilan berhitung adalah keterampilan dasar yang menjadi tujuan pertama dan utama, selain membaca dan menulis. Keterampilan berhitung ini mesti dilatihkan kepada siswa sehingga siswa benar-benar menguasainya. Keterampilan berhitung termasuk di dalamnya keterampilan dalam mengoperasikan bilangan-bilangan adalah modal dasar bagi siswa untuk menyelesaikan masalah yang berkaitan dengan pemecahan masalah matematis.

Menilik pada salah satu teori perkembangan kognitif dari Piaget (Frenky, 2010), siswa pada jenjang sekolah dasar berada pada taraf berpikir konkret. Berdasarkan pada teori ini, siswa dapat memahami suatu objek apabila objek tersebut disajikan dalam konteks yang sifatnya konkret. Selain itu, menurut Wijaya (2012:24) menyatakan tentang pentingnya belajar matematika secara bermakna. Dengan belajar bermakna, siswa akan memiliki banyak kesempatan untuk mengkontruksi pengetahuannya sendiri tanpa peran guru yang dominan. Tugas guru berikutnya adalah memfasilitasi siswa agar siswa dapat mengambil peran dalam belajar bermakna melalui proses doing math. Proses doing math tersebut dapat ditempuh bila siswa dihadapkan pada situasi yang berhubungan dengan kehidupan nyata (Zulkardi, 2010). Wijaya (2012:31) kemudian menegaskan bahwa ketika anak belajar matematika terpisah dari pengalaman nyata, anak akan segera melupakannya dan tidak akan bisa menerapkannya. Dalam hal ini belajar matematika sesungguhnya tidak cukup dengan mengandalkan keterampilan mekanistik tetapi memerlukan suatu proses yang disebut repersonalisasi. Repersonalisasi adalah melakukan matematisasi seperti yang dilakukan matematikawan, menghubungkan antara konsep dengan konsep sebelumnya, serta mengaitkan antara konsep dengan konteksnya (Rosmalia, 2015:2).

Pemahaman ini merupakan implikasi dari filosofi suatu pendekatan pembelajaran yang disebut pembelajaran matematika realistik (PMR). PMR adalah pendekatan pembelajaran yang menempatkan matematika sebagai aktivitas manusia dan bersumber dari dunia nyata atau dunia yang dekat dengan 
siswa. Gagasan utama pembelajaran realistik adalah matematika sebagai aktivitas manusia (human activity) yang bermula dari situasi realistic (Afriansyah, 2016), siswa mengkontruksi sendiri modelmodel matematika, kemudian menggunakan matematika untuk menyelesaikan masalah kontekstual (Danoebroto, 2008:77).

PMR menawarkan suatu proses pembelajaran secara bertahap mulai dari konsep yang sederhana menuju pada konsep yang lebih kompleks. Rangkaian proses ini merumuskan suatu learning trajectory (lintasan belajar) yang harus muncul dalam pembelajaran. Agar learning trajectory ini dapat muncul dalam pembelajaran, maka guru harus bisa merumuskan suatu antisipasi didaktis pedagogis melalui Hypothetical Learning Trajectory (HLT). HLT dapat dilakukan melalui analisis terhadap hambatanhambatan belajar (learning obstacles) yang dihadapi oleh siswa sehingga penyebab kesulitan siswa dapat diantisipasi atau bahkan dihindari. HLT merujuk pada rencana pembelajaran berdasarkan antisipasi belajar siswa yang mungkin dicapai dalam proses pembelajaran yang didasari pada tujuan pembelajaran matematika yang diharapkan pada siswa, pengetahuan, dan perkiraan tingkat pemahaman siswa, serta pilihan aktivitas matematika secara berurut (Fuadiah, 2017). Dengan demikian, tugas guru adalah membuat suatu desain didaktis pembelajaran yang bisa memberikan antisipasi didaktis pedagogis sehingga suatu topik pembelajaran bisa disampaikan sesuai dengan karakteristik serta tujuan yang ingin dicapai.

Sementara itu, Muslich (Diba, Zulkardi, \& Saleh, 2009) mengemukakan lima prinsip pembelajaran yang berorientasi pada potensi yang dimiliki siswa, yaitu: (1) Kegiatan yang berpusat pada siswa, (2) belajar melalui berbuat, mengembangkan kecerdasan intelektual, emosional, spiritual, dan sosial, (4) belajar sepanjang hayat, dan (5) belajar mandiri dan belajar bekerja sama. Kelima prinsip pembelajaran serta ciri-ciri dari pembelajaran yang berpusat pada siswa tersebut salah satunya tercermin pada pembelajaran matematika realistik (PMR).

Dalam pandangan PMR, siswa tidak bisa dianggap sebagai penerima pasif, namun pembelajaran matematika hendaknya memberikan kesempatan kepada siswa untuk menemukan kembali (reinvent) matematika melalui bimbingan guru dengan memanfaatkan berbagai kesempatan dan situasi nyata yang dialami siswa (Shadiq \& Mustajab, 2010). PMR ini menjadi dasar dari desain seluruh konteks dan aktivitas pembelajaran (Afriansyah, 2017). Wijaya (2012) mengemukakan bahwa pembelajaran realistik merupakan pendekatan pembelajaran yang mengutamakan kebermaknaan konsep matematika sebagai titik awal (starting point) pembelajaran. Kebermaknaan ini dibangun melalui pemahaman terhadap konteks dunia nyata yang kemudian berkembang menjadi konsep yang dipahami oleh siswa melalui matematisasi.

\section{Mosharafa: Jurnal Pendidikan Matematika}


Proses matematisasi ini menjadi hal yang sangat penting dan menjadi bagian yang harus dibangun dengan kokoh agar pemahaman siswa terhadap matematika menjadi utuh.

Pada PMR terdapat dua bentuk matematisasi, yaitu: matematisasi horizontal dan matematisasi vertikal. Treffers (van Den Heuvel-Panhuizen, 2003) menjelaskan bahwa matematisasi horizontal terkait dengan tools matematika yang ditampilkan dan digunakan untuk mengorganisasikan dan memecahkan masalah dalam kehidupan sehari-hari, sedangkan matematisasi vertikal merupakan pengorganisasian kembali dan operasi yang dilakukan oleh siswa dalam sistem matematika itu sendiri. Contoh dari aktivitas matematisasi horizontal adalah mengidentifikasi masalah matematika ke dalam konteks yang lebih umum, mengadakan penskemaan, merumuskan dan memvisualisasikan masalah kedalam cara yang berbeda, menemukan relasi (hubungan), dan menemukan keteraturan. Sedangkan contoh aktivitas matematisasi vertikal adalah menyatakan suatu hubungan dalam suatu rumus, membuktikan keteraturan, menggunakan model-model yang berbeda, merumuskan konsep matematika baru, dan menggeneralisasikan.

Agar matematisasi dapat terjadi, PMR hendaknya memperhatikan lima karakteristik PMR. Menurut de Lange
(Suwarsono, 2001), kelima karakteristik PMR tersebut mencakup hal-hal sebagai berikut.

1) Menggunakan konteks nyata (real context).

2) Menggunakan model-model, skemaskema, diagram-diagram, simbolsimbol.

3) Menggunakan proses yang konstruktif dalam pembelajaran, dimana siswa mengkonstruksi sendiri penyelesaian soal.

4) Terdapat Interaksi yang multiarah, baik antar siswa maupun antara siswa dan guru.

5) Keterkaitan antara unit matematika dan masalah-masalah yang ada dalam dunia ini.

Sesuai dengan permasalahan di SDI Nurul Hasanah Kota Tangerang, studi mengenai desain didaktis pada topik pecahan menarik untuk ditelusuri lebih lanjut melalui penelitian. Alasannya paling tidak karena dua hal; (1) perbedaan karakteristik siswa sekolah dasar antara tingkat perkembangan berpikir siswa yang berada pada taraf berpikir konkret dengan hakikat matematika sebagai pengetahuan abstrak (Amir, 2014), (2) masalah pecahan adalah masalah yang senantiasa inheren dalam aktivitas pembelajaran matematika sekolah dasar yang tidak hanya berdampak pada pencapaian hasil belajar siswa saja tetapi akan berefek pada kemampuan siswa di masa mendatang. 


\section{Metode}

Penelitian ini dirancang dengan menggunakan metode penelitian desain (design research method). Sedangkan tahapan penelitiannya mengacu pada tahapan penelitian desain dari Gravemeijer \& Cobb (2006), mencakup: 1) persiapan penelitian (preparing for the experiment) atau desain awal (preliminary design), 2) pelaksanaan desain eksperimen (design experiment), atau eksperimen pembelajaran (teaching experiment), dan 3) analisis tinjauan/analisis data yang diperoleh dari tahap sebelumnya (retrospective analysis). Sesuai dengan karakteristik dari penelitian desain, tujuan dari penelitian ini memberikan suatu pertimbangan yang baik terhadap proses pembelajaran serta penurunan teori pembelajaran empiris. Karena teori yang dikembangkan bersifat empiris, maka teori yang dikontruksi dari hasil penelitian ini berupa teori instruksional lokal (local instructional theory) yang memberikan jawaban secara umum terhadap suatu topik yang diajarkan. Sementara itu proses untuk mendapatkan teori instruksional lokal ini muncul dari proses perancangan pembelajaran yang bersifat siklikal, sehingga hasil dari HLT tetap juga merupakan HLT atau dikatakan sebagai dugaan teori intruksional lokal. Skema dari tahapan penelitian desain ini secara eksplisit diilustrasikan pada gambar berikut.

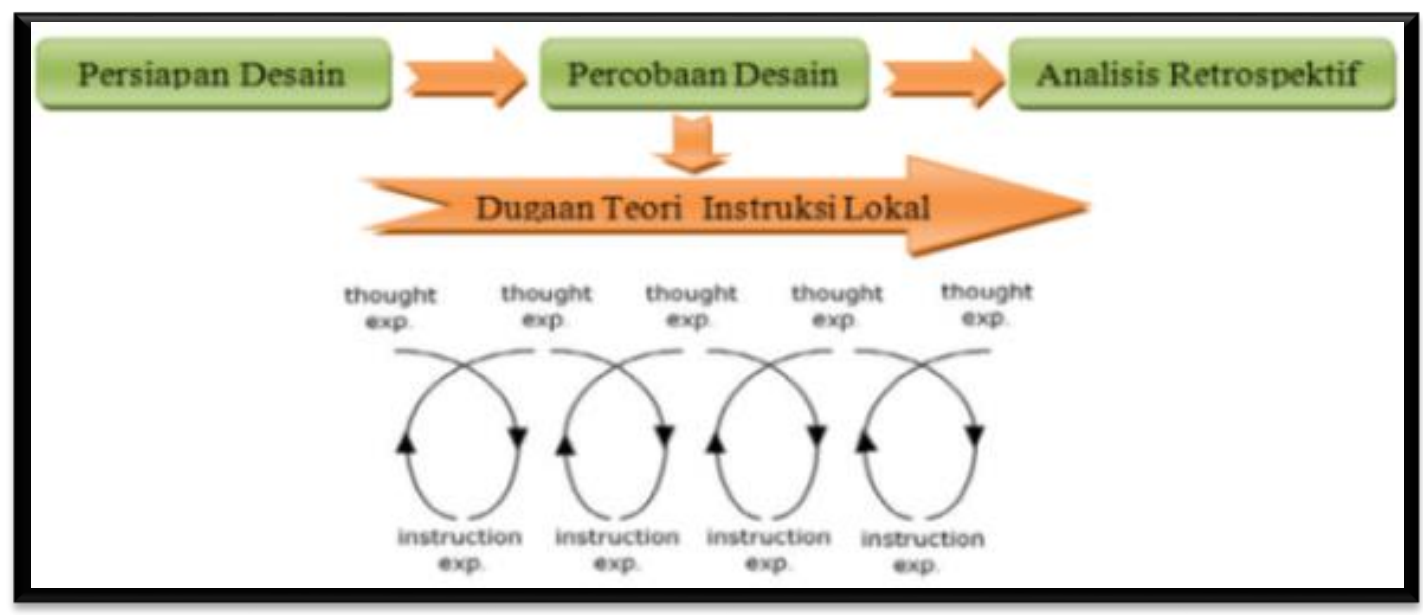

Gambar 1. Siklus Design Research (Gravemijer, 2004)

Penelitian ini dilakukan pada semester ganjil tahun akademik 2017/2018. Sebagai subjek adalah 4 siswa kelas VA, 25 siswa kelas VB di Sekolah Dasar Islam Nurul Hasanah Kota Tangerang. Berbagai sumber dikumpulkan dari rekaman vidio, dokumentasi, data tertulis, wawancara, dan observasi untuk mendapatkan informasi tentang pemahaman dan penguasaan siswa terhadap materi pecahan. 
Pada tahap ini dilakukan penganalisisan terhadap hypothetical learning trajectory (HLT) pada topik pecahan di mana siswa dapat mengkontruksi pengetahuan formal dari pengetahuan informal yang dibangun melalui proses matematisasi. Analisis bersumber/diperoleh dari kajian literatur (termasuk didalamnya hasil penelitian terdahulu), analisis hambatan belajar (learning obstacle) siswa pada topik

Tabel 1.

Hypothetical Learning Trajectory (HLT)

\begin{tabular}{|c|c|c|c|}
\hline Aktivitas & $\begin{array}{c}\text { Tujuan } \\
\text { Pembelajaran }\end{array}$ & Deskripsi Aktifitas & Konjektur Pemikiran Siswa \\
\hline $\begin{array}{l}\text { Memotong } \\
\text { Pizza }\end{array}$ & $\begin{array}{l}\text { Siswa dapat } \\
\text { mengetahui } \\
\text { makna pecahan }\end{array}$ & $\begin{array}{l}\text { Guru mendorong siswa untuk } \\
\text { menyebutkan nilai pecahan. }\end{array}$ & $\begin{array}{l}\text { Siswa memotong pizza secara sembarang } \\
\text { Siswa memotong pizza sesuai intruksi guru } \\
\text { Siswa menyebutkan potongan pizza bernilai satuan }\end{array}$ \\
\hline $\begin{array}{l}\text { Menggambar } \\
\text { Potongan } \\
\text { Pizza }\end{array}$ & $\begin{array}{l}\text { Siswa dapat } \\
\text { menyebutkan nilai } \\
\text { pecahan tertentu }\end{array}$ & $\begin{array}{l}\text { Siswa bekerja dalam kelompok } \\
\text { untuk menggambar potongan pizza } \\
\text { berbentuk lingkaran yang dipotong- } \\
\text { potong. } \\
\text { Siswa mewarnai salah satu } \\
\text { potongan pizza atau potongan } \\
\text { lingkaran }\end{array}$ & $\begin{array}{l}\text { Siswa menggambar potongan lingkaran secara } \\
\text { sembarang sehingga potonganya luasnya juringnya } \\
\text { tidak sama } \\
\text { Siswa menggambar potongan lingkaran secara } \\
\text { proporsional }\end{array}$ \\
\hline $\begin{array}{l}\text { Juring } \\
\text { Pecahan }\end{array}$ & $\begin{array}{l}\text { Siswa dapat } \\
\text { menyebutkan } \\
\text { pecahan senilai. }\end{array}$ & $\begin{array}{l}\text { Siswa bekerja dalam kelompok } \\
\text { untuk membandingkan dua } \\
\text { pecahan yang sama melalui } \\
\text { beberapa juring pecahan yang } \\
\text { sama. }\end{array}$ & $\begin{array}{l}\text { Siswa mencoba meletakan juring pada lingkaran } \\
\text { utama (tempat juring pecahan) sehingga diperoleh } \\
\text { nilai pecahan yang tepat. } \\
\text { Siswa membandingkan beberapa juring yang } \\
\text { menunjukan nilai pecahan yang sama. }\end{array}$ \\
\hline $\begin{array}{l}\text { Petak } \\
\text { pecahan }\end{array}$ & $\begin{array}{l}\text { Siswa dapat } \\
\text { menjumlahkan } \\
\text { dua pecahan. }\end{array}$ & $\begin{array}{l}\text { Dalam kegiatan kelompok siswa } \\
\text { mewarnai petak-petak pecahan } \\
\text { yang menunjukan pecahan tertentu } \\
\text { Guru mendorong siswa dengan } \\
\text { menujukan bahwa gabungan dari } \\
\text { petak-petak yang diwarnai } \\
\text { menunjukan hasil penjumlahan dua } \\
\text { pecahan yang senilai }\end{array}$ & $\begin{array}{l}\text { Siswa dapat mewarnai petak dengan tepat pada } \\
\text { penjumlahan pecahan yang berpenyebut sama } \\
\text { Siswa mengalami kebuntuan untuk menggabungkan } \\
\text { petak yang diwarnai pada penjumlahan pencahan } \\
\text { yang berpenyebut tidak sama }\end{array}$ \\
\hline $\begin{array}{l}\text { Menjumlahka } \\
\text { n dua } \\
\text { pecahan }\end{array}$ & $\begin{array}{l}\text { Siswa dapat } \\
\text { menjumlahkan } \\
\text { dua pecahan yang } \\
\text { berpenyebut yang } \\
\text { tidak sama }\end{array}$ & $\begin{array}{l}\text { Guru mendorong siswa mencari } \\
\text { pecahan senilai dari dua pecahan } \\
\text { sehingga penyebut dari kedua } \\
\text { pecahan tersebut dapat } \\
\text { dijumlahkan. }\end{array}$ & $\begin{array}{l}\text { Siswa mendapatkan pecahan senilai dari dua pecahan } \\
\text { tetapi kedua pecahan tersebut tidak dapat } \\
\text { dijumlahkan. } \\
\text { Siswa mendapatkan pecahan senilai dengan cara } \\
\text { mengalikan pembilang dan penyebut masing-masing. }\end{array}$ \\
\hline
\end{tabular}

Tabel 1 di atas, digunakan sebagai Selanjutnya, desain HLT didiskusikan rujukan utama dalam menyusun perangkat dengan guru, kemudian diterapkan dalam pembelajaran: skenario, bahan ajar, penelitian pendahuluan (pilot experiment). lembar kerja siswa, dan alat evaluasinya. 


\section{HaSil dan Pembahasan}

\section{A. Kegiatan 1}

Sebelum dilakukan penelitian, dilakukan tes awal atau pretes untuk mengetahui kemampuan awal matematika. Tujuan dari aktivitas ini adalah siswa mampu memahami dan menentukan pecahan, pecahan senilai dengan menggunakan konteks pizza. Kegiatan 1 yang dilakukan siswa dalam riset ini adalah memotong pizza menjadi beberapa bagian melalui bentuk dan besarnya potongan pizza terhadap pizza yang sebelumnya dengan ukuran sama besar. Kegiatan 1 dilakukan untuk mengeksplorasi pengetahuan siswa dalam memahami tentang pecahan. Pada penelitian ini, siswa dibagi dalam 4 kelompok yang masing-masing kelompok terdiri dari beberapa siswa yang memiliki kemampuan matematika yang heterogen. Setiap kelompok akan mendapat satu pizza yang masih utuh, kemudian masingmasing kelompok dibantu oleh peneliti dan guru kelas untuk memotong pizza menjadi beberapa bagian yang sama besar.

Pada kegiatan ini, diharapkan siswa dapat memahami dan menentukan pecahan senilai dan penjumlahan pencahan dengan menggunakan konsteks pizza. Berikut ini adalah kutipan diskusi:

Peneliti: "Untuk menentukan pecahan 1/2, bagaimana caranya!"

Natasya: " caranya, memotong pizza pada bagian tengah menjadi 2 bagian yang sama besar?"

Peneliti : " Jika hasil potongan pizza tadi diambil 1 bagian, apa maknanya"
Natasya : "saya mendapatkan setengah bagian pak"

Peneliti : "Sekarang potong lagi pizza, sehingga menjadi 4 bagian" Sekarang apa makna $1 / 4$ ?"

Natasya: "1 bagian potongan pizza dari 4 potongan pizza".

Peneliti : "Biar jelas, coba sketsa potongan pizza?"

Dari transkip percakapan 1, terlihat bahwa siswa tidak mengalami kesulitan dalam menjelaskan konsep pecahan.

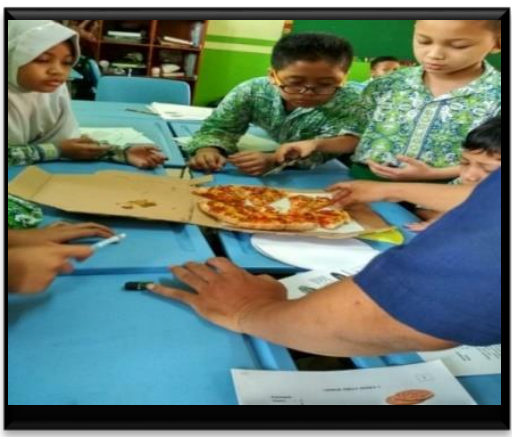

Gambar 2. Simulasi Memotong Pizza Menentukan Makna Bagian.

Kemudian hasil simulasi dtulis dalam lembar kerja siswa (LKS), seperti pada Gambar 3 berikut:

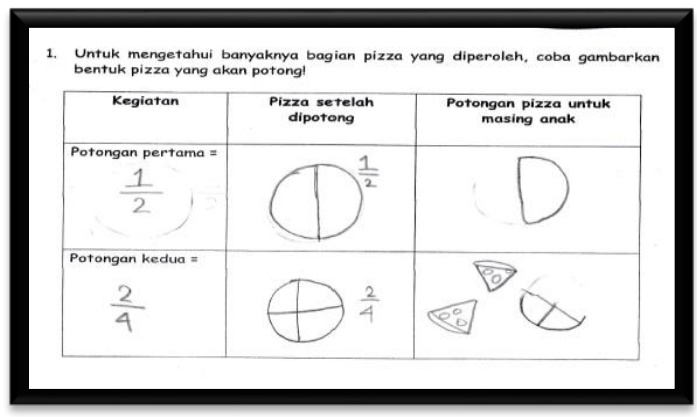

Gambar 3. Pecahan dengan Pizza.

Pada Gambar 3, setelah dipotong pizzanya siswa menggambar hasil potongan pada LKS yang telah ditentukan. Siswa membuat pecahan dengan memotong pizza yang telah disiapkan oleh peneliti dengan ukuran yang sudah 
ditentukan, yaitu 2 bagian dan 4 bagian potongan. Pada lembar kerja siswa 1, siswa bekerja secara berkelompok untuk menentukan potongan atau bagian pizza jika dipotong dengan ukuran yang sama.

Selanjutnya, siswa menentukan pecahan senilai berdasarkan hasil simulasi yang telah dilkukan kelompok dengan potongan pizza. Beberapa permasalahan cara membagi pizza kepada kelompok belajar menjadi diskusi yang menarik. Berikut hasil LKS, temanya yang disajikan pada Gambar 4 berikut:

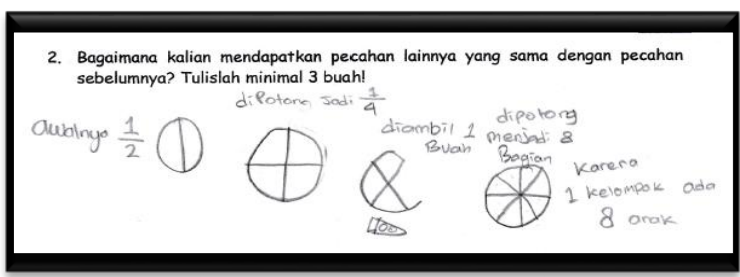

Gambar 4. Pecahan Senilai.

Pada ekplorasi menentukan pecahan senilai, siswa melakukan kegiatan lanjut dengan cara memotong gambar lingkaran, sebagai wujud bentuk pizza dengan pecahan setengah. Mula-mula siswa membagi lingkaran menjadi 4 bagian. Siswa kemudian meletakan 2 buah juring pecahan masing-masing bernilai seperempat. Nilai kedua buah juring ini menjadi 2/4, karena ada 2 bagian dari 4 bagian lingkaran dasar. Siswa kemudian mencocokkan kedua juring pecahan tersebut dengan juring pecahan setengah sehingga diperoleh $1 / 2$ sama dengan $2 / 4$.

\section{B. Kegiatan 2}

Pada kegiatan 2, aktifitas yang diberikan siswa yaitu menggunakan pecahan senilai dengan menggunakan juring pecahan. Pada aktifitas ini, siswa akan mencocokan bentuk juring yang telah potong sebelumnya dengan lingkaran penuh. Berikut aktifitas 2 yang disajikan pada Gambar 5 berikut:

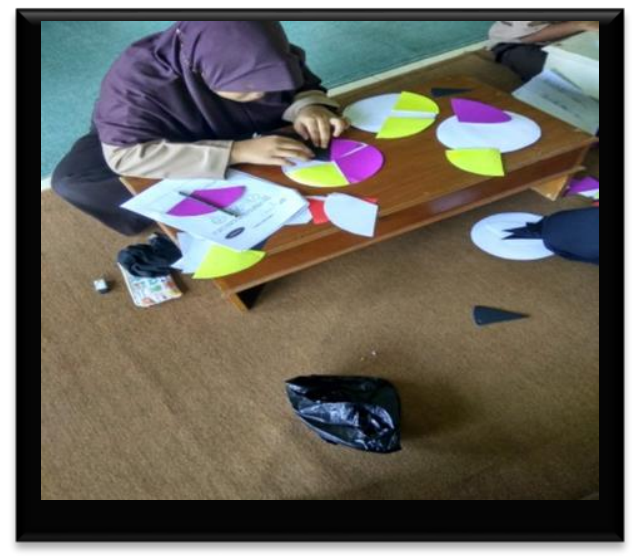

Gambar 5. Kegiatan 2.

Untuk mengetahui tentang aktifitas kegiatan 2, berikut aktifitas selama riset yang terangkum dalam percakapan antara peneliti dengan siswa

Peneliti : "Coba pisahkan dulu juring berdasarkan ukuranya"

Fatin : "sudah pak"

Peneliti : " Coba pasang juring yang ukuranya sama sehingga menutupi lingkaran dibawahnya.

Fatin: "Yang ukuran besar atau kecil dulu pak? Peneliti : "Coba mulai juring yang besar dulu"

Fatin : "Pak, saya dapat dua during besar ini menenutupi lingkaran"

Peneliti : "ada berapa jumlah juringnya?"

Fatin :" 2 pak"

Peneliti : "Masih ingat, pizza kemarin kan?". Berapa nilai 1 bagian juring ini terhadap seluruh lingkaran?

Fatin : "1/2 pak" 


\section{Kegiatan 3}

Pada kegiatan 3, aktifitas siswa yang dilakukan adalah eksplorasi pecahan senilai dengan menggunakan kertas yang dilipat. Berdasarkan permasalahan yang diberikan pada LKS muncul pertanyaan siswa baik pada guru (peneliti) maupun sesama siswa. Berikut ini kutipan diskusi:

Peneliti : "Bagaimana cara menentukan pecahan senilai?".

Nayla: "dilakukan dengan melihat ukuran lipatan".

Zahra: "saya biasanya dengan melihat ukuran arsiran dan lipatan".

Peneliti :"maksutnya apa?"

Zahra : "Pertama saya buat arsiran pecahan yang dimaksut, terus pada kertas arsiran dilipat lagi".

Peneliti : " apakah sulit menentukan pecahan senilai?"

Zahra: " kalo saya tidak menemukan masalah"

Dari percakapan di atas, nampak bahwa siswa mampu menentukan pecahan senilai yang dilakukan dengan menggunakan media kertas yang dilipat. Selanjutnya akan dilakukan operasi penjumlahan dengan menggunakan pecahan senilai. Siswa dapat menentukan penjumlahan yang penyebutnya sama dengan menggunakan bantuan kertas diarsir.

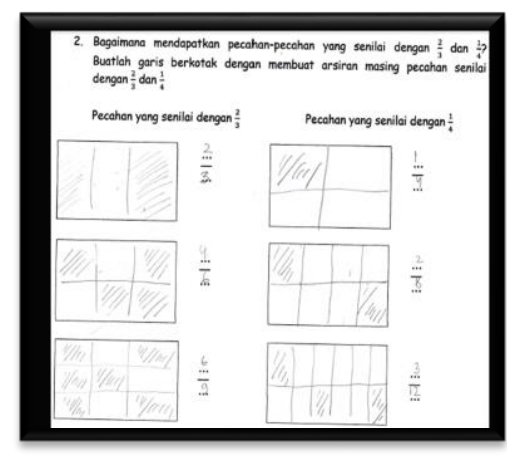

Gambar 6. Kegiatan 4.

Mosharafa: Jumal Pendidikan Matematika

Volume 8, Nomor 1, Januari 2019

Copyright @ 2019 Mosharafa: Jurnal Pendidikan Matematika
Pada akhir siklus atau akhir penelitian diberikan tes akhir (postes). Berdasarkan hasil tes antara pretes dan postes terdapat perbedaan yang sangat signifikan kemampuan pemahaman materi pecahan. Melalui aktifitas desain riset yang telah dilakukan, ternyata dapat dianalisis bahwa pengetahuan siswa tentang materi pecahan mengalami peningkatan dari kemampuan pemahaman materi pecahan.

Selanjutnya analisis soal postes yang dilakukan setelah desain riset dilakukan dengan pendekatan pembelajaran matematika realistik. Berdasarkan temuan hasil postes, sebagian besar siswa mengalami kemajuan dalam memahami dan menyelesaikan masalah matematika. Misalnya pada saat pretes hampir semua belum bisa menyelesaikan. Tetapi pada saat postes, sebagian besar siswa bisa menyelesaikan masalah matematika. Berdasarkan analisis hasil postes, bahwa siswa kelas $V$ SDI Nurul Hasanah mengalami peningkatan kemampuan pemahaman dan kemampuan penalaran matematis dalam menyelesaikan masalah matematika. Selain itu, siswa merasa lebih nyaman dan senang dengan pembelajaran yang dilakukan dengan desain riset.

\section{Retrospective analysis}

Pada tahap ini, HLT yang telah dibuat dibandingkan dengan proses pembelajaran siswa yang sebenarnya yaitu menunjukan pembelajaran sesuai dengan HLT yang didesain dan siswa memahami materi pecahan. Hal ini terlihat dari hasil analisis retrospektif, ketika hasil pretes dilakukan diperoleh hasil yang nilainya 
dibawah kreteria ketuntasan minimum dan sebagian besar dari jawaban pretes, siswa belum mampu menjawab soal yang diberikan oleh peneliti. Sedangkan berdasarkan hasil postes yang dilakukan, dapat di analisis bahwa sebagian besar siswa mampu menjawab dan mengungkapkan penalaran secara baik dalam menyelesaikan soal matematika yang diberikan oleh peneliti. Berdasarkan analisis tersebut dapat disimpulkan bahwa kemampuan siswa dan kemampuan pemahaman matematis siswa mengalami peningkatan yang signifikan.

Berdasarkan rumusan masalah, hasil analisis data, dan temuan maka diperoleh penelitian ini tergambar dari teori instruksional lokal (local instructional theory) yakni berupa suatu pertimbangan yang baik terhadap proses pembelajaran yang memberikan jawaban secara umum terhadap suatu topik yang diajarkan. Design research dilakukan dalam tiga tahap, yaitu desain pendahuluan, percobaan mengajar yang terdiri siklus 1 dan siklus 2, dan tahap ketiga analisis retrospektif.

Penelitian ini didesain untuk mengetahui bagaimana peran konteks dapat mendukung pemahaman konsep pecahan kepada siswa. Oleh karena itu, tujuan desain riset dilakukan untuk memahami konsep pecahan melalui aktivitas-aktivitas yang dilakukan untuk menjadikan siswa tidak mengalami kesulitan dalam memahami konsep pecahan. Berdasarkan desain HLT yang telah disusun dan dilakukan oleh peneliti. HLT disusun untuk membantu peneliti dalam merencaranakan pembelajaran materi pecahan sehingga dapat diantisipasi kemungkinan-kemungkinan terjadinya masalah pemahanan materi pecahan.

Memahami konsep pecahan pada pembelajaran matematika realistik (PMR) dengan menggunakan konteks pizza akan memberikan stimulus pengalamanpengalaman sebelumnya. Pendekatan PMR yang dilakukan terdiri serangkaian tahapan kegiatan penelitian yang menjadi acuan utama dalam setiap aktivitas pembelajaran yang telah dilaksanakan pada setiap siklus. Pendesainan aktivitas pembelajaran atau penelitian ini berpedoman pada karakteristik PMR yaitu dimulai dengan penggunaan konteks pada awal pembelajaran yang bertujuan untuk meningkatkan motivasi dan ketertarikan siswa dalam belajar (de Lange dalam wijaya, 2012). Tahapan penelitian PMR dilaksanakan menggunakan konteks pizza sebagai titik awal dalam mengawali materi pecahan.

Pendekatan matematika realistik (PMR) memiliki peranan penting untuk menghasilkan lintasan belajar siswa dalam pembelajaran matematika materi pecahan. Melalui aktivitas-aktivitas seperti memotong, melipat, menggambar maka pemahanan matematika materi pecahan lebih mudah dipahami. Lintasan belajar 
yang dihasilkan dalam penelitian ini adalah lintasan-lintasan belajar yang dilalui siswa melalui dari penggunaan konteks pizza dalam mengenal pecahan dan pecahan senilai. Selain itu, dengan menggunakan konstek kertas yang dilipat dan diarsir, aktivitas berbasis pengalaman telah membantu meningkatkan pemahaman siswa tentang konsep pecahan senilai. Sehingga dalam proses penentukan penjumlahan pecahan siswa mampu melakukan dengan menggunakan konsep senilai.

\section{Penutup}

Pendekatan matematika realistik (PMR) memiliki peranan penting untuk menghasilkan lintasan belajar siswa dalam pembelajaran matematika materi pecahan. Melalui aktivitas-aktivitas seperti memotong, melipat, menggambar maka pemahanan matematika materi pecahan lebih mudah dipahami. Lintasan belajar yang dihasilkan dalam penelitian ini adalah lintasan-lintasan belajar yang dilalui siswa melalui dari penggunaan konteks pizza dalam mengenal pecahan dan pecahan senilai. Selain itu, dengan menggunakan konstek kertas yang dilipat dan diarsir, aktivitas berbasis pengalaman telah membantu meningkatkan pemahaman siswa tentang konsep pecahan senilai. Sehingga dalam proses penentukan penjumlahan pecahan siswa mampu melakukan dengan menggunakan konsep senilai. Pada PMR, proses pembelajaran

Mosharafa: Jumal Pendidikan Matematika Volume 8, Nomor 1, Januari 2019 Copyright $\odot 2019$ Mosharafa: Jurnal Pendidikan Matematika dikelas melalui tahapan dari tahap informal menuju tahap formal

Beberapa rekomendasi diantaranya adalah pelaksanaan siklus 1 perlu kerjasama yang baik dengan guru kelas, sehingga akan menjadi masukan siklus 2, dan kelompok belajar sebaiknya ukuran kecil agar lebih maksimal untuk mengetahui lintasan belajar

\section{DAfTAR Pustaka}

Afriansyah, E. A. (2016). Investigasi Kemampuan Problem Solving dan Problem Posing Matematis Mahasiswa via Pendekatan Realistic. Mosharafa: Jurnal Pendidikan Matematika, 5(3), 269-280.

Afriansyah, E. A. (2017). Desain Lintasan Pembelajaran Pecahan melalui Pendekatan Realistic Mathematics Education. Mosharafa: Jurnal Pendidikan Matematika, 6(3), 463474.

Amir, A. (2014). Pembelajaran matematika SD dengan menggunakan media manipulatif. Pedagogik, 6(1), 72-89.

Anwar, Z. (2012). Pelaksanaan Pembelajaran Matematika di Sekolah Dasar. Jurnal Penelitian IImu Pendidikan, 5(2), 24-32.

Danoebroto, S.W. (2008). Improving problem solving skill using the PMRI and metacognitive training. Jurnal Penelitian dan Evaluasi Pendidikan, 1(11), 73-87.

Diba, F., Zulkardi, \& Saleh, T. (2009). Pengembangan materi pembelajaran bilangan berdasarkan pendidikan 
matematika realistik untuk siswa kelas $\checkmark$ sekolah dasar. Jurnal Pendidikan Matematika, 3(1), 33-46.

Frengky. (2010). Model pembelajaran matematika siswa kelas satu sekolah dasar. Jurnal Psikologi, 35(2), 151-163

Fuadiah, N. F. (2017). Hypothetical Learning Trajectory pada Pembelajaran Bilangan Negatif Berdasarkan Teori Situasi Didaktis di Sekolah Menengah. Mosharafa: Jurnal Pendidikan Matematika, 6(1), 13-24.

Gravemeijer \& Cobb. (2006). Design Research from a Learning Perspective, dalam Educational Design Research. New York : Routledge.

Nuraeni, E, Lidinillah, D.A.M., \& Sakinatussaadah, A. (2012). Model disain didaktis pembagian pecahan berbasis pendidikan matematika realistik untuk siswa kelas $V$ Sekolah Dasar. Prosiding Seminar Nasional Matematika dan Pendidikan Matematika FMIPA UNY Yogyakarta, 297-308.

Rosmalia, N.L. (2015). Desain Didaktis Luas Permukaan dan Volume Limas pada Pembelajaran Matematika di SMP. (Skripsi). Bandung: Jurusan Pendidikan Matematika, Universitas Pendidikan Indonesia.

Shadiq, F., \& Mustajab, N.A. (2010). Pembelajaran matematika dengan pendekatan realistik di SMP. Yogyakarta: P4TK Matematika.
Suwarsono. (2001). Beberapa permasalahan yang terkait dengan upaya implementasi pendidikan matematika realistik di indonesia. Makalah. Disampaikan dalam Seminar Nasional Pendidikan Matematika Realistik di USD, 14-15 November 2001.

van Den Heuvel-Panhuizen, M. (2003). The didactical use of models in realistic mathematics education: An example from a longitudinal trajectory on percentage. Educational Studies in Mathematics, 54, 9-35.

Wijaya, A. (2012). Pendidikan Matematika Realistik: Suatu Alternatif Pendekatan Pembelajaran Matematika. Yogyakarta: Graha IImu.

Yeni, R.F.(2013). Desain pembelajaran aturan sinus dan aturan cosinus berbasis PMRI untuk mengetahui strategi siswa. Jurnal Kreano, Jurusan Matematika FMIPA UNNES, 4(1) hlm. 88-97

Zulkardi. (2010). How to Design Mathematics Lesson based on the Realistic Approach?. Terdapat pada http://eprints.unsri.ac.id/692/1/rme.h tml. [On line]. Diakses tanggal 17 Juni $2017 a$ 